\title{
ASYNAPSIS AND SPONTANEOUS CHROMOSOME BREAKAGE IN SCILLA
}

\author{
HUBERT REES \\ John Innes Horticultural Institution and Department of Genetics, \\ University of Birmingham \\ Received 27.i.5I
}

\section{INTRODUCTION}

IN I928 Beadle and McClintock described a recessive Mendelian factor causing irregular meiosis in the form of a failure of pairing of homologous chromosomes at metaphase in Zea mays. At the time it was assumed that this abnormality was due to a failure of pachytene pairing, and the term asynapsis was used to describe it. Later Beadle (I933) reported that in "asynaptic" maize pachytene pairing was apparently normal, so that initial failure of pairing was not the cause of the later failure at metaphase. For convenience the term asynapsis was retained to describe the failure of metaphase pairing ( $c f$. Koller on Pisum, I938; and others); and it is in the same sense that the term is used in this account, implying that asynapsis may be due to effects becoming visible after a normal pachytene pairing as well as to failure of initial pachytene association.

Asynapsis has been described in a number or organisms, resulting from a variety of causes, genotypic and environmental. Among the most notable examples is that of "asynaptic" strains of Crepis capillaris (Richardson, I935). Irregularities leading to non-pairing at metaphase were extensively reviewed by Darlington in 1937. In all these cases chiasma frequency shows a normal, unimodal variation.

In the following account asynapsis of a new kind is described in conjunction with spontaneous chromosome breakage. Such breakage in pollen mother cells would seem to be of rare incidence. A case mentioned in Tulipa orphanidea (Darlington and Upcott, I940) was beyond analysis. Breakage may or may not have been associated with reduced chiasma frequency and consequent asynapsis.

\section{MATERIAL AND METHOD}

Bulbs of Scilla sibirica (variety Spring Beauty) from three sources were examined. The bulbs from two sources were triploid $\left(2 n=3^{x}=\mathrm{I} 8\right)$. Of seven bulbs examined from another source one was triploid, the other six diploid $(2 n=12)$. In all six diploid plants spontaneous chromosome breakage was found in pollen mother cells. Evidently the "variety" consisted of two clones, one diploid and one triploid. 
For anther squashes two methods proved satisfactory at the later stages of meiosis: (I) combined staining and fixing of fresh material using aceto orcein (La Cour, I94I), (2) fixation in three parts alcohol

TABLE I

Distribution of cells lagging at prophase and of cells showing chromosome breakage at metaphase, in two bulbs

\begin{tabular}{|c|c|c|c|c|c|c|}
\hline \multirow{2}{*}{ Bulbs } & \multicolumn{3}{|c|}{ Prophase } & \multicolumn{3}{|c|}{ Metaphase } \\
\hline & $\begin{array}{l}\text { Number of } \\
\text { cells lagging }\end{array}$ & $\begin{array}{l}\text { Normal } \\
\text { cells }\end{array}$ & $\begin{array}{l}\text { Per cent. } \\
\text { lagging cells }\end{array}$ & $\begin{array}{c}\text { Cells with } \\
\text { chromosome } \\
\text { breakage }\end{array}$ & $\begin{array}{c}\text { Normal } \\
\text { cells }\end{array}$ & $\begin{array}{l}\text { Per cent. } \\
\text { cells with } \\
\text { breakage }\end{array}$ \\
\hline I & 69 & 896 & $7 \cdot I$ & 52 & 845 & $5 \cdot 8$ \\
\hline 2 & 24 & I 397 & $I \cdot 6$ & 15 & 1589 & 0.94 \\
\hline
\end{tabular}

and one part iron acetate in glacial acetic acid and staining in iron aceto carmine. For sectioning, anthers were fixed in La Cour's ${ }_{2} \mathrm{BE}$ and stained by the Crystal Violet method.

\section{FREQUENCY AND DISTRIBUTION OF ABNORMAL CELLS}

The abnormalities are confined to pollen mother cells. The proportion of cells showing chromosome breakage varies from 0.94
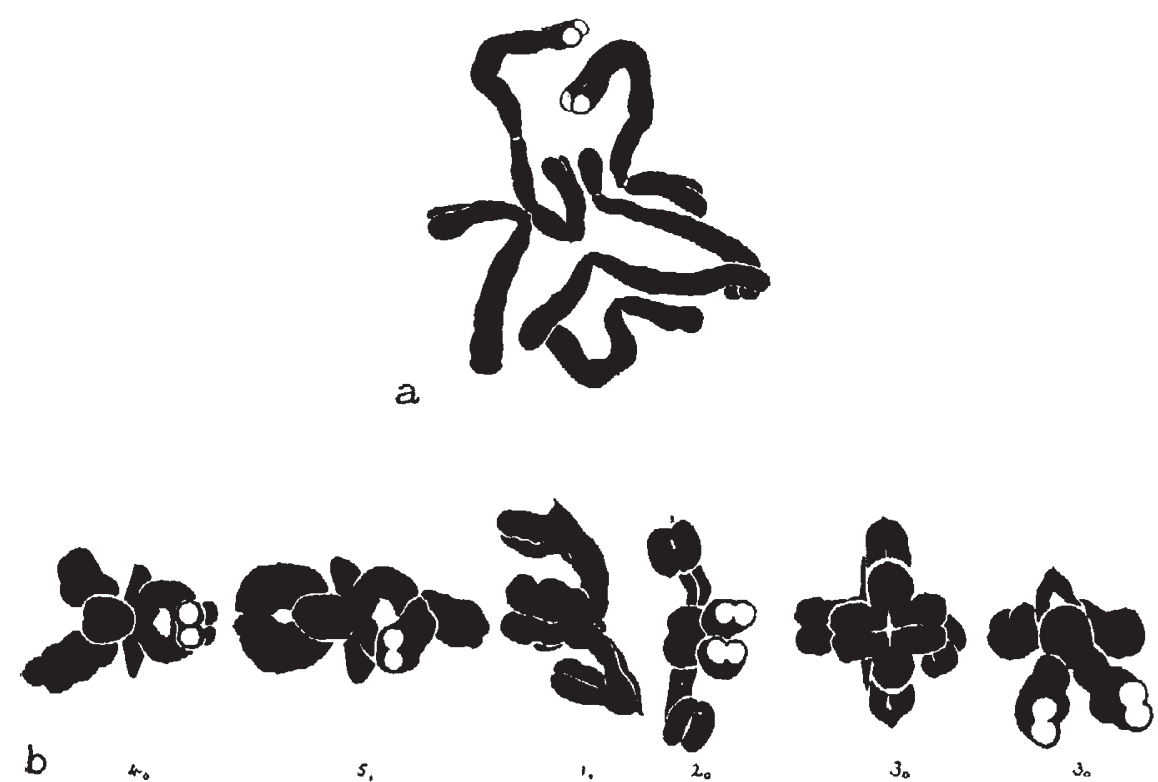

FIG. 1.-(a) Pollen grain mitosis in Scilla sibirica. (b) Normal bivalenta at metaphase.

per cent. in one plant to 5.8 per cent. in another. From examination of longitudinal sections of anthers the abnormal cells appear to be 
localised only in so far as that none are seen towards the distal and proximal regions; they are all scattered in the mid regions of the loculi.

\section{MEIOSIS IN CELLS WITH NO CHROMOSOME BREAKAGE}

Invariably six bivalents are found at metaphase (text fig. I $b$ ), and meiosis follows a normal course. Bridges were seen at first anaphase in about 2 per cent. of cells, indicating inversion crossing over (plate, fig. 2). Of 22 cells with bridges counted out of 825 pollen mother cells at first anaphase in one plant, 5 cells show single bridges without fragments. In these cases the bridges may well be the result of failure of division of end genes (sister reunion), brought about by nucleic acid upset, as suggested by Darlington and Upcott (I940) in explanation of similar bridges seen in Tradescantia (Darlington, I937), and in Pisum (Koller, I938), and also at mitosis in Trillium (Darlington and La Cour, I 945).

Pollen grains appear normal and divide regularly (text fig. I $a$ ).

\section{MEIOSIS IN CELLS WITH CHROMOSOME BREAKAGE}

The breakage of chromosomes becomes evident generally at metaphase except in a few cells where highly fragmented nuclei occur which seem incapable of organising a recognisable metaphase. The degree of breakage is extreme and accurate analysis of breakage and reunion impossible in all but a few cells (text figs. $3 a$ and $3 b$ ). Difficulty of anaphase separation (see text fig. 2b) may be a consequence of obstructed reproduction of chromosomes, as in Trillium (Darlington and La Cour, I945). Chromosome contraction is semi mitotic.

There is no evidence of chiasma formation; hence there are no bivalents, and the first division is mitotic. All the univalents or centric "univalent" fragments divide at the first division in the great majority of cells (text figs. $3 a$ and $3^{b}$ ). During this division the acentric fragments fall apart. Only in one cell (text fig. 2c) was there any sign of a second division. The cells, containing a number of micronuclei, generally degenerate after one division.

Apart from the disorganisation brought about by fragmentation, the fact that all the univalents divide at the first division may in itself preclude a second division, for in consequence, the interphase centromeres and gene strings are "single," in contrast to their potentially and actually "double" state at normal meiotic interphase. Univalents divide once only (Darlington, I939), and if all divide together as in this instance the "single" condition of interphase centromeres is probably effective in not initiating a second division. In the one exception it is reasonable to assume that not all the centric pieces had divided at first anaphase.

Text figs. $3 a$ and $3^{b}$ show homologous univalents in close association at anaphase, which leads to the assumption that asynapsis 
is not brought about by failure of pachytene pairing, but by failure of chiasma formation between paired homologues. This was found to be the case in "asynaptic" Crepis (Richardson, 1935), in Pisum (Koller, 1938) and in Lilium-testaceum (Ribbands, 1937). Un-
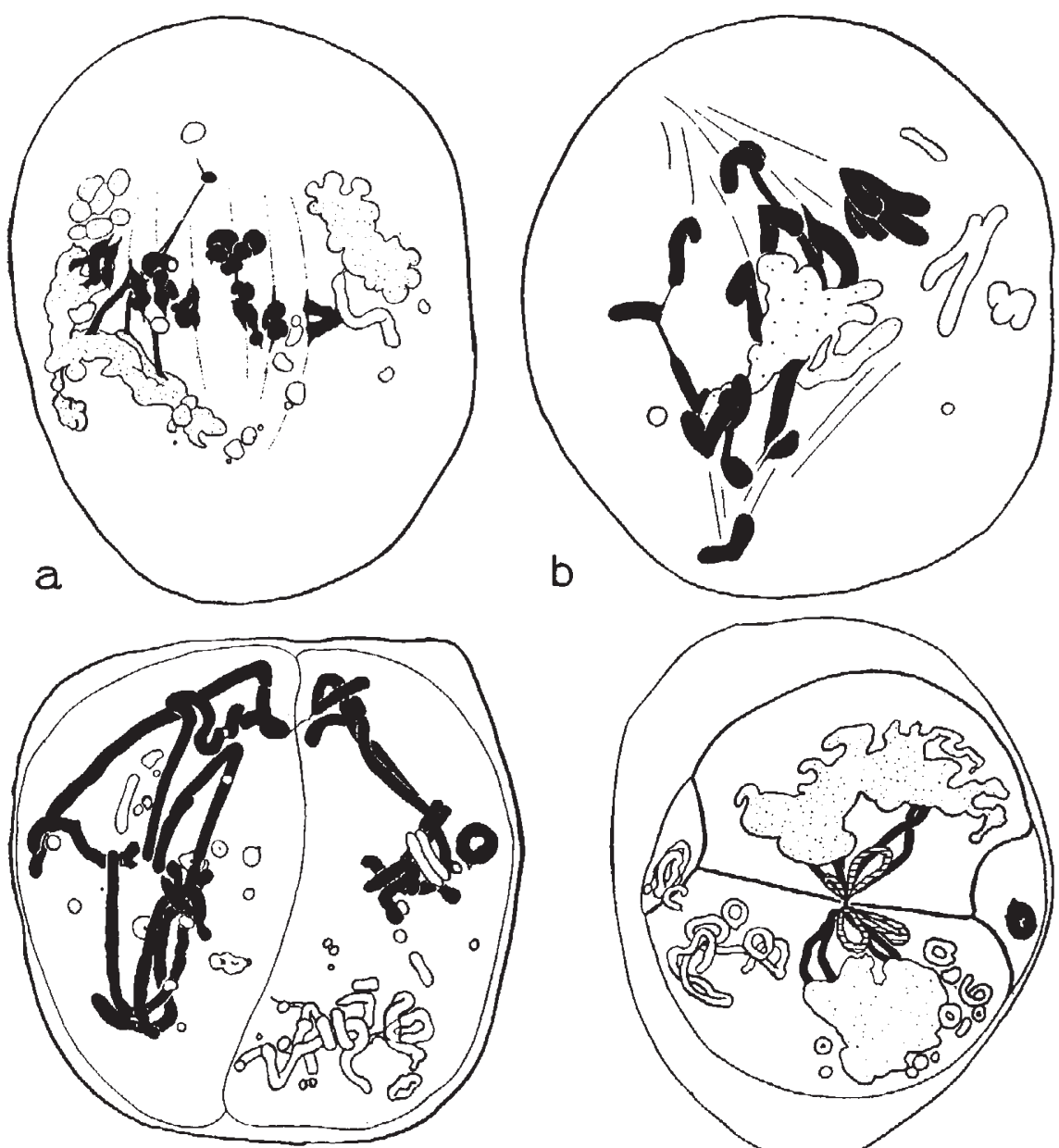

C

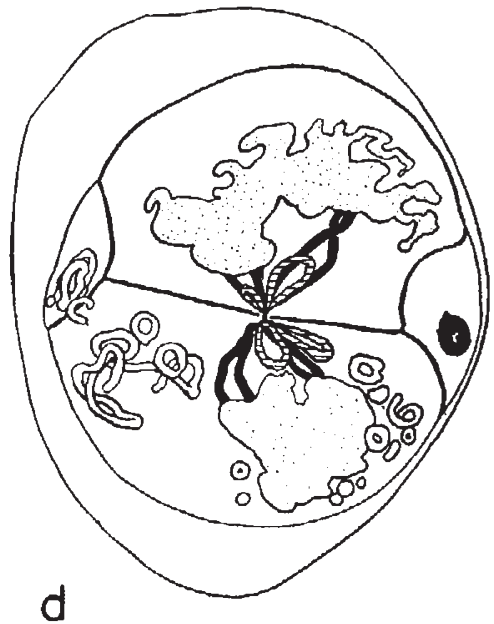

Fig. 2.- (a) First anaphase in an abnormal cell. Chromatid bridges are the result of sister reunions following chromosome breakage. (b) First anaphase showing bent spindle. At 9 o'clock failure of separation presumably ariscs through failure of reproduction of the chromosome. (c) Second division. (d) First telophase. Chromatid bridges are trapped by the cell wall formed. Centric fragments are shown in black. $\times 960$.

fortunately preparations of early stages of meiosis in this material were not good enough to verify this assumption cytologically.

Spindles are frequently bent and stretched (text fig. $2 b$ ), a feature noticed in many cases of asynapsis (Dobzhansky in Drosophila, 1934; Brieger in Nicotiana, I 934). 


\section{KIND OF CHROMOSOME BREAKAGE}

Metaphase and anaphase configurations point to chromosome breaks $\left(\mathrm{B}^{11}\right)$, followed sometimes by reunion, giving rise to, (I) chromatid bridges at anaphase (text figs. $2 a, 2 b, 3 a$ and $3 b$ ), (2) monocentric rings (text figs. $2 c$ and $2 d$ ), (3) dicentric rings (text fig. 3), (4) acentric fragments which often form rods or rings by reunion. The consequences of breakage and reunion are in fact, from the point of resultant chromosome configurations, similar to those induced artificially by X-rays, etc.
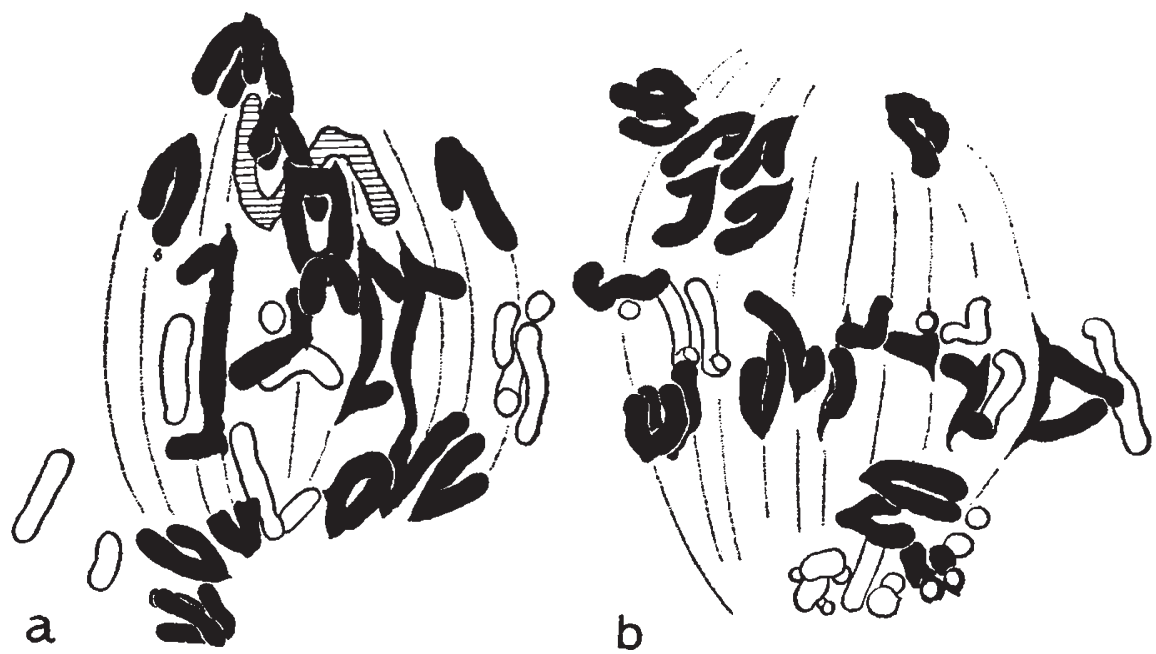

FIG. 3.- (a) First anaphase. Homologous univalents at I 2 o'clock and 7 o'clock are closely associated. The cross hatched structure is interpreted as being a displaced centric fragment which has undergone sister reunion. Two dicentric chromatid rings have separated towards each pole. Three chromatid bridges appear on the equator. (b) First anaphase. Paired homologous univalents appear at each pole, chromatid bridges at the equator. No bivalents appear in either case. In both cells the centric pieces are drawn in black. $\times 960$.

There is evidence for fragmentation resulting from severing, by cell wall formation of chromatid loops (text fig. $2 d$ ), the loops probably being a consequence of "slack" chromatid bridges, bridges such as may arise by sister reunion at a distance from the centromere greater than half the length of the spindle axis. In another case (plate, fig 3) part of the chromosome complement of a cell showing much breakage appears trapped by the cell wall between itself and an adjacent normal cell, so that some parts of the chromosomes are contained in the "normal " partner. This in itself would no doubt result in fragmentation, but as this is not a constant feature associated with abnormal cells it cannot be an important contributing cause of breakage. It does however suggest that irregularity in some cases arises at pre-meiotic mitosis. 


\section{TIMING ANOMALIES}

At early prophase a number of cells lag (plate, fig. I). Thus when the majority of cells are at early diplotene a minority are at leptotene. The frequency of these laggard cells corresponds with the frequency of cells which show breakage at metaphase in anthers of other flowers of the same plant (table $\mathrm{I}$ ).

It appears therefore that a timing difference at early stages is associated with the breakage evident at later stages. It was mentioned earlier that some cells by virtue of very great fragmentation seem incapable of forming a metaphase plate. These cells probably often disappear from the record, and this would at least partly explain, in each of the above analyses, the slightly lower frequency of cells showing breaks at metaphase than of cells lagging at prophase in the same plant.

Metaphase in affected and normal cells, as we see in plate, fig. 2, is synchronous. The initial lagging must therefore be followed by

TABLE 2

A comparison of diameters of normal and abnormal cells at prophase and at first metaphase

\begin{tabular}{|c|c|c|c|c|c|c|c|}
\hline \multicolumn{2}{|c|}{ Diameters in $\mu$} & $35-40$ & $40-4.5$ & $45-5^{\circ}$ & $5^{0-55}$ & $55-60$ & $\begin{array}{c}\text { Mean diameter } \\
\text { in } \mu\end{array}$ \\
\hline Prophase . & $\begin{array}{l}\text { normal cells } \\
\text { lagging cells }\end{array}$ & $\begin{array}{l}6 \\
\cdots\end{array}$ & $\begin{array}{l}8 \\
4\end{array}$ & $\begin{array}{l}I \\
6\end{array}$ & ‥ & $\dddot{2}$ & $\begin{array}{l}4^{1} \\
49\end{array}$ \\
\hline Metaphase & 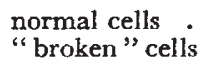 & $\begin{array}{l}2 \\
\cdots\end{array}$ & $\begin{array}{l}5 \\
\cdots\end{array}$ & $\begin{array}{l}8 \\
2\end{array}$ & $\dddot{6}$ & $\dddot{7}$ & $\begin{array}{l}45 \\
54\end{array}$ \\
\hline
\end{tabular}

The probability of obtaining by chance such differences in diameter between the two classes of cells at prophase and at metaphase is less than 0.001 . The results were tested by the $t$ method.

an acceleration of the division process. Such an acceleration of retarded cells has been inferred by Darlington and La Cour from observations of cells X-rayed to produce chromosome breakage (1945).

\section{CELL SIZE DIFFERENCE}

Table 2 shows that a significant difference exists between cell diameters of normal and abnormal cells at prophase and at metaphase. As these measurements were made from squash preparations an error accentuating the difference may have been introduced, but nevertheless that a significant difference does occur is beyond doubt (plate, figs. I and 2).

A somewhat similar correlation between size difference and difference in behaviour was found by Beadle (1933), where failure of cell wall formation following the first meiotic division was a characteristic of "giant" pollen mother cells in maize. 


\section{CAUSE AND EFFECT}

The increased volume suggests the possibility that a differentiation in the irregular cells has led to a prolonged growth phase, that is to protein synthesis at the expense of nucleic acid synthesis. Later, the onset of division in these sick cells may be due to stimulation by the

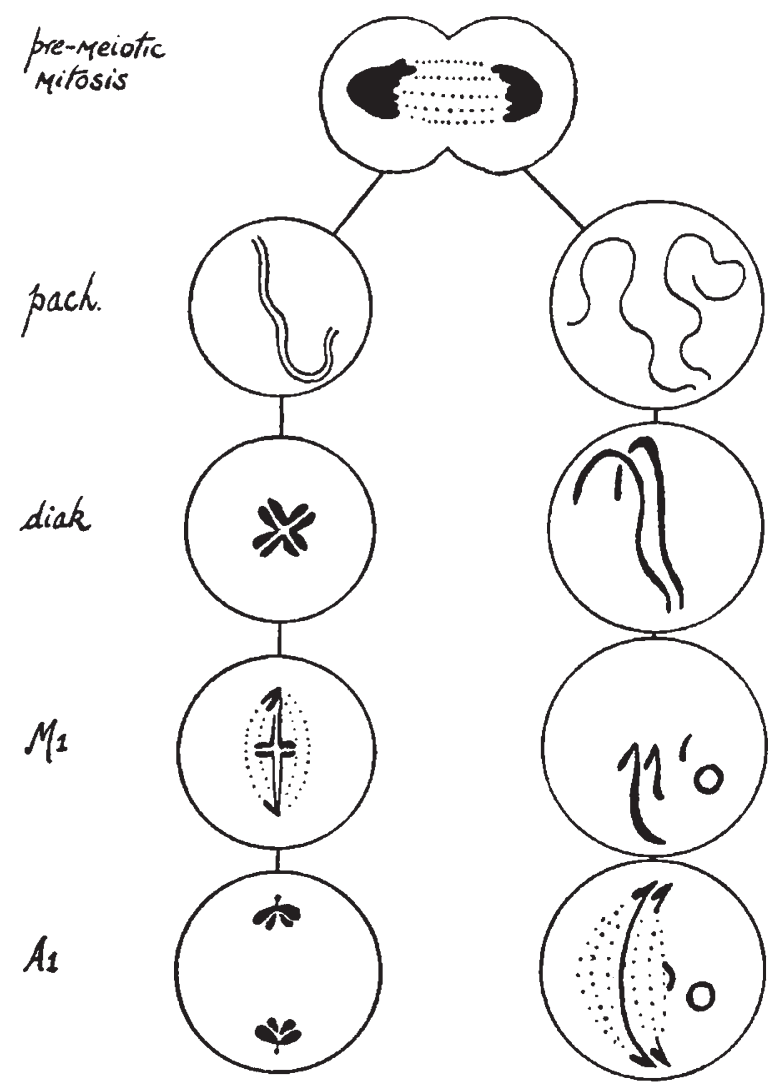

\section{Abnormality resulting trom differentiation of sister cells following pre-meiotic milosis. \\ Diagram.}

surrounding actively dividing cells. There would in consequence be a reduced precocity of meiosis in the irregular cells, and failure of chiasma formation is probably due to a reduced precocity of meiosis (Darlington, 1937).

One can visualise on this basis a sequence of events similar to that suggested to occur in " asynaptic" maize by Beadle (1933), that is 
a precocious splitting at pachytene with consequent failure of chiasma formation between the paired chromosomes. In maize, however, asynapsis was not complete.

The property of the plant to show abnormality in its pollen mother cells is interpreted as being genetically controlled. The threshold of expression of the irregularity must be a delicate one, even to the point of differentiation between sister cells at pre-meiotic mitosis (plate, fig. 3). An analogous sharp threshold for breakage was inferred by Darlington and Upcott (1940), and by Darlington and La Cour (1945). Such a controlled change, it is suggested, may well take the form of a reduction in cell wall permeability which may lead to gross differences in cell activity; the consequences of this being first, to prolong growth and thereby retard the division cycle of the cell, and, secondly, by the products of this altered metabolism, to bring about chromosome breakage. Abnormality may, as has been inferred, arise at the pre-meiotic mitosis.

That asynapsis is the direct consequence of chromosome breakage seems unlikely. Mather (1934) and others have shown that fragmentation induced artificially does not prevent the formation of chiasmata, even when the degree of fragmentation is high. Asynapsis in Scilla sibirica is complete in abnormal cells, chromosome breakage variable. Both abnormalities would therefore appear to be independent consequences of a common metabolic disturbance.

\section{SUMMARY}

I. Asynapsis in conjunction with spontaneous chromosome breakage is described in pollen mother cells of Scilla sibirica.

2. The frequency of affected cells varies from 0.94 per cent. to 5.8 per cent. in the plants examined.

3. Meiosis is normal in cells without chromosome breakage.

4. Lagging at early prophase and increased volume are characteristic of abnormal cells.

5. Breakage is of the $\mathrm{B}^{11}$ type, with results similar to those brought about artificially by X-rays, etc.

6. Asynapsis and chromosome breakage are interpreted as being independent consequences of a common cell disturbance with a sharp threshold, differentiating genetically equivalent premeiotic cells.

I am pleased to thank Dr Darlington and Mr La Cour for their advice and criticism, and for providing facilities which enabled me to carry out this work at the John Innes Horticultural Institution.

\section{REFERENCES}

BEADLE, G. W., AND MCCLINTOCK, B. 1928. A genic disturbance of meiosis in Zea mays. Science, 68,433 .

BEADLE, G. W. 1932. A gene in Zea mays for failure of cytokinesis during meiosis.

Cytologia, 3, 142-1 55 . 
BEADLE, G. W. I933. Further studies in asynaptic maize. Cytologia, 4, 269-287. BRIEger, F. I934. Ablenf der Meiose bei volliges Asyndese. Ber. Deuts. Bot. Ges., 52, I $49-153$.

DARLington, c. D. 1937. Recent Advances in Cytology. London : Churchill.

DARLington, c. D. I939. Misdivision and genetics of the centrnmere. F. Genet., $37,34 \mathrm{I}-364$.

DARLiNGTON, c. D., AND UPCOTT, M. B. 1940. Spontaneous chromosome change. F. Genet., 4I, 297-338.

DARLINGTON, c. D., AND LA couR, L. F. 1945. Chromosome breakage and the nucleic acid cycle. J. Genet., 46 , 180-267.

Dobzhansky, TH. I934. Studies on hybrid sterility. I. Spermatogenesis in pure and hybrid Drosophila pseudo-obscura. Zeitz. Zellf. u. mikr. Anat., 2I, I69-223.

MATHER, K. I934. The behaviour of meiotic chromosomes after X-irradiation. Hereditas, 20, 303-322.

RIBbands, C. R. 1937. The consequencies of structural hybridity at meiosis in Lilium testaceum. F. Genet., 35, I-24.

Richardson, м. м. I935. Meiosis in Crepis I and II. 7. Genet., 3i, IoI-II7, II 9-I 43 . 


\section{Plate}

Microphotographs of meiosis in Scilla sibirica showing asynapsis and spontaneous chromosome brrakage.

(1) Prophasc of meiosis. Note size and timing differences. Aceto carmine $\times 160$.

(2) First anaphase. Aceto carmine $\times 160$.

(3) Normal and abnormal first anaphase in sister cells. Acetu-orcein $\times 1300$.

(4) Second division in an abnormal cell. Aceto-orcein $\times 1300$.

(5) First telophase in a cell with chromosome breakage. Aceto-orcein $\times 1300$. 
$0,70 \pi$ 1,0 की

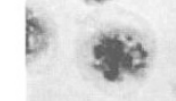
- 64 $+\infty$

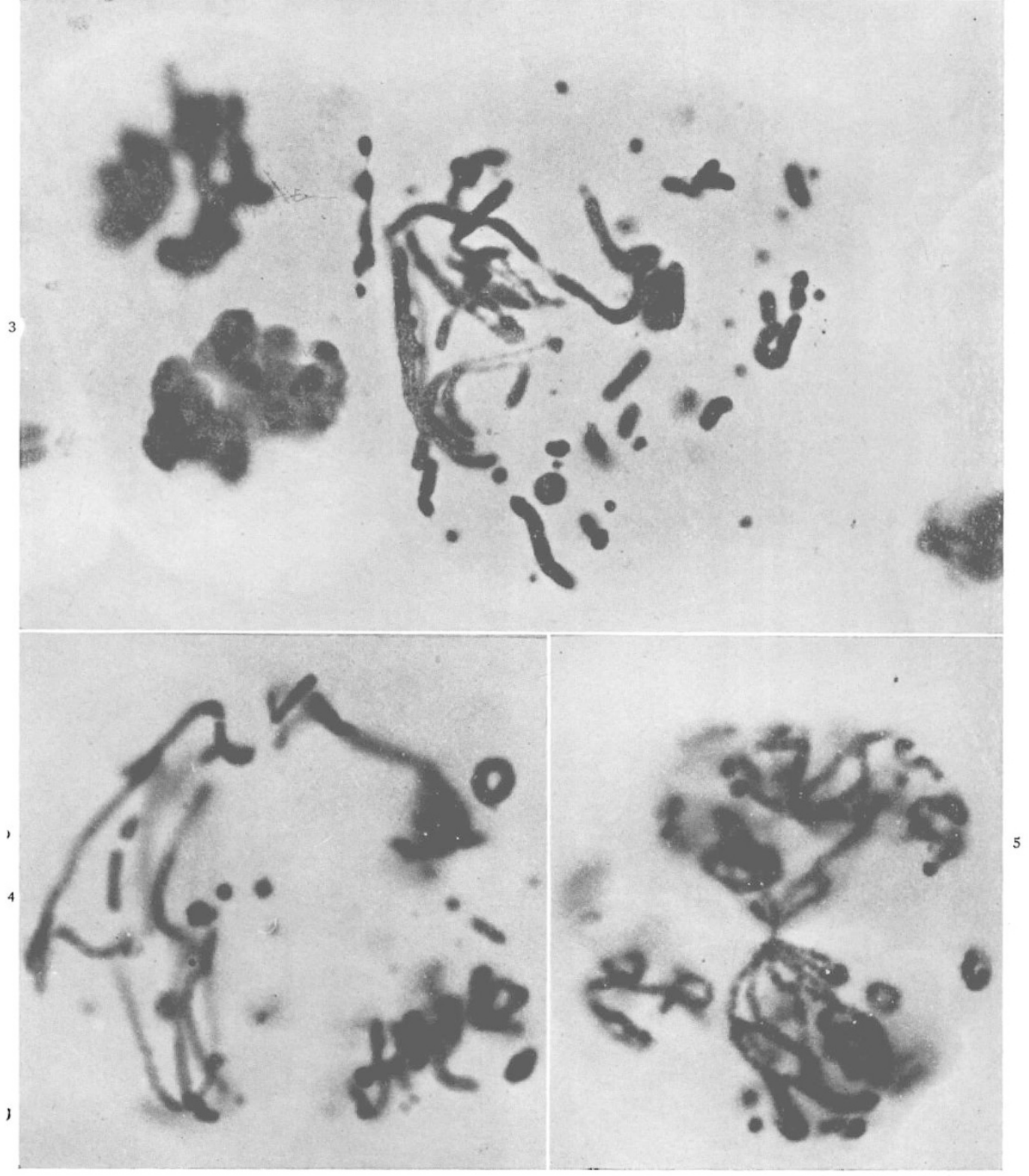

